\title{
THE INFLUENCE OF FWA CHEMICAL CONSTITUTION TO THE WHITENESS AND UV PROTECTION OF COTTON AND COTTON/POLYESTER BLEND*
}

Lea Botteri ${ }^{1}$, Tihana Dekanić ${ }^{1}$, Anita Tarbuk ${ }^{1 * *}$, Dragan Đorđević ${ }^{2}$

1University of Zagreb, Faculty of Textile Technology, Zagreb, Croatia

2University of Niš, Faculty of Technology, Textile Department, Leskovac, Serbia

It is well known that the optimal concentration of fluorescent whitening agent (FWA) in the bath results in high whiteness of single component textiles. At the same time, due to fluorescence of FWA, the higher UV protection is achieved as well. However, for the textile blends it is not so easy to achieve. Depending on the fabric chemical composition, different FWAs must be applied. Therefore, the influence of FWA chemical constitution to the whiteness and UV protection of cotton and cotton/polyester blend were researched in this paper. For that purpose, cotton and cotton/polyester blended (50\%/50\%) fabrics was treated with four different FWAs by Huntsman, Uvitex® brand: BHT, RSB, NFW and EBF. Spectral remission before and after FWA treatment was measured on a remission spectrophotometer Spectraflash SF 300, Datacolor. Whiteness degree was calculated according to ISO 105-J02:1997, and the Tint Deviations and its coloristic meanings were determined according to Griesser. The UV protection of cotton and cotton/polyester fabrics treated with FWA was determined according to AS/NZS 4399:2017 using transmission spectrophotometer Cary 50/Solascreen, Varian. Based on the results obtained,the stilbene disulphonic acid triazine derivative (Uvitex® RSB) can be recommended for use on a cotton/polyester blend.
(ORIGINAL SCIENTIFIC PAPER)

UDC 677.21/.494.674:677.26

DOI 10.5937/savteh2102066B
Keywords: cotton, cotton/polyester blend, UV protection, FWA, degree of whiteness

\section{Introduction}

To achieve high whiteness, textile fabric needs to be treated with fluorescent whitening agent (FWA). The activity of fluorescent whitening agent is based on fluorescence. The molecules that have planar configuration, conjugated double bonds or high resonance stability and electron donating group show the phenomenon of fluorescence. The FWA molecule goes to electronically-excited state by absorbing energy of UV radiation (UV-R), and then it has to lose that energy by emitting radiation to regain its ground state. According to the Stokes Law, the frequency of fluorescence radiation is lower than that of excitation light and the curve of emission is mirror-like to the curve of absorption. In the case of FWAs, that means that FWA molecules absorb ultraviolet light (300-400 nm) and emit it as visible light, usually in the blue region of the spectrum $(400-500 \mathrm{~nm})$. The emission of blue light neutralizes the yellow tone of fabric, achieving the impression of high whiteness [1-5]. Fluorescent whitening agent for cotton fabric by chemical composition are mainly stilbene derivatives. Most often they are diaminostilbene derivatives that differ in substituents and the number of sulfonate groups. However, for cellulose distyrylbiphenyl derivatives and triazolyl-stilbene derivatives can be used as well. For polyester fabric, FWAs are usually benzoxazole derivatives. Therefore, for the application on cotton/polyester blend FWAs should be carefully chosen. Additionally, by choosing the appropriate FWA with the maximum emission at different wavelengths, the whiteness of different tones can be obtained: blue $435-440 \mathrm{~nm}$, purple $430-435$ $\mathrm{nm}$, and blue-green $440-450 \mathrm{~nm}$.

It should be noted that FWA treatment also results in better UV protection due to the absorption of ultraviolet radiation. (UV-R) [5-14]. Long exposure to solar ultraviolet radiation, along with the amount of skin pigmentation, is the primary cause of skin cancer $[6,15,16]$. The proper and early photoprotection reduces the risk of subsequent skin cancer occurrence. This can be achieved by reducing the time of exposure time to sunlight, using sunscreen and protective textiles. Since good UV protection with textiles depends on a large number of factors [5-20], such as, the type of fiber, fabric surface and construction, porosity, density, moisture content, presence of nanoparticles, as well as type and concentration of applied dyestuff, FWAs or UV-B protective agents, designing and engineering of UV protective fabrics always

\footnotetext{
*The paper was presented at $14^{\text {th }}$ Symposium with international participation "NOVEL TECHNOLOGIES AND ECONOMIC DEVELOPMENT", Faculty of Technology in Leskovac, 22-23 October, 2021.

${ }^{* *}$ Author address: Assoc. Prof. Anita Tarbuk, PhD,

University of Zagreb Faculty of Textile Technology, Prilaz baruna Filipovića 28a, HR-10000 Zagreb, Croatia

e-mail: anita.tarbuk@ttf.unizg.hr

The manuscript received: 06. 09. 2021.

Paper accepted: 11. 10. 2021.
} 
presents a challenge. Untreated cotton fabric, as celluIosic material, provides low UV protection. On the other hand, due to the benzene rings, polyester fabric gives better UV protection than cellulose $[6,12]$.

Since different FWAs must be applied depending on the chemical composition of the fabric, this paper investigates UV protection of cotton fabrics and its mixture with polyester after treatment with four different fluorescent whitening agents.

\section{Experimental}

Cotton fabric (CO) and cotton/polyester blended (50\%/50\%) fabric (CO/PES), panama woven, mass per unit area $150 \mathrm{~g} / \mathrm{m}^{2}$ were used in this paper. The fabrics were treated with four different FWAs by Huntsman, Uvitex® brand (Tab.1).

Table 1. FWA chemical constitution and characteristics

\begin{tabular}{|c|c|}
\hline FWA characteristics & Structural formula \\
\hline $\begin{array}{l}\text { Uvitex BHT } \\
\text { C.I. Fluorescent Brightener } 113 \\
\text { Diamino stilbene disulphonic acid } \\
\text { derivative } \\
\lambda \lambda_{\max }=440 \mathrm{~nm} \\
\text { Cellulosic fibers, polyamide, wool, } \\
\text { silk and their blends }\end{array}$ & $\mathrm{Na}^{+}$ \\
\hline $\begin{array}{l}\text { Uvitex NFW } \\
\text { C.I. Fluorescent Brightener } 351 \\
\text { Distyryl biphenyl derivative } \\
\lambda_{\max }=435-440 \mathrm{~nm} \\
\text { polyamide, wool, silk, cellulosic } \\
\text { fibers and their blends }\end{array}$ & \\
\hline $\begin{array}{l}\text { Uvitex RSB } \\
\text { Stilbene disulphonic acid triazine } \\
\text { derivative } \\
\lambda_{\max }=435-440 \mathrm{~nm} \\
\text { Cellulosic fibers and } \\
\text { polyester/cellulose blends }\end{array}$ & $\mathrm{H}$ \\
\hline $\begin{array}{l}\text { Uvitex EBF } \\
\text { C.I. Fluorescent Brightener } 190 \\
\text { Benzoxazole derivative } \\
\lambda_{\max }=430-440 \mathrm{~nm} \\
\text { polyester, acetate, triacetate, } \\
\text { polyvinylchloride, propylene fibers } \\
\text { and their blends }\end{array}$ & \\
\hline
\end{tabular}

FWAs' were used in wide concentration range: 0.5 , 1, 2 and $5 \%$ owf by batch wise method having LR 1:30 at $100{ }^{\circ} \mathrm{C}$ for $30 \mathrm{~min}$ in stainless-steel bowls (Linitest, Original Hanau). After the treatment, the fabrics were airdried. Labels and treatments are listed in Tab. 2.

Table 2. Labels and treatments

\begin{tabular}{ll}
\hline Label & Treatment \\
\hline CO & Chemically bleached cotton fabric \\
CO/PES & Cotton/PES blended fabric \\
$\ldots$...FWA_... & Treatment with FWA (Uvitex - BHT, RSB, NFW, EBF) \\
$\ldots$.._conc. & Concentration of optical brightener $-0.5,1,2,5 \%$ owf \\
\hline
\end{tabular}

Spectral remission (R [\%]) was measured on a remission spectrophotometer Spectraflash SF 300, Datacolor. Fabric whiteness $\left(\mathrm{W}_{\mathrm{CIE}}\right)$ according to ISO 105-J02:1997 Textiles - Tests for colour fastness - Part J02: Instrumental assessment of relative whiteness, Tint Deviation (TD) and its coloristic meanings according to Griesser [21] were calculated automatically.

Ultraviolet protection factor (UPF), UV-A and UV-B transmission, and UV protection rating of cotton and cotton/polyester fabrics before and after FWA treatment was determined according to AS/NZS 4399:2017 Sun protective Clothing - Evaluation and Classification using transmission spectrophotometer Cary 50/Solascreen, varian. 


\section{Results and discussion}

In this paper, the influence of FWA chemical constitution on the whiteness and UV protection of cotton and cotton/polyester blend was researched. For that purpose, $\mathrm{CO}$ and CO/PES fabrics were treated with four different FWAs. Spectral remissions are presented in Fig.1.

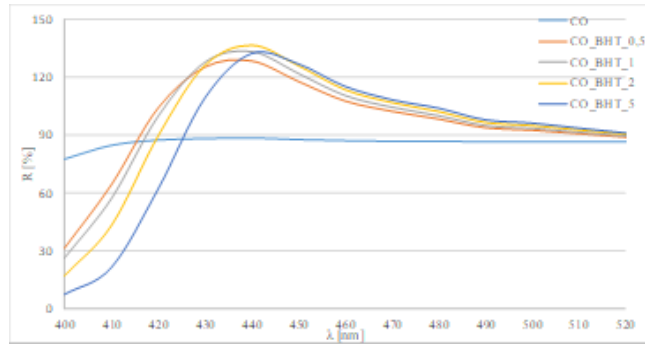

a)

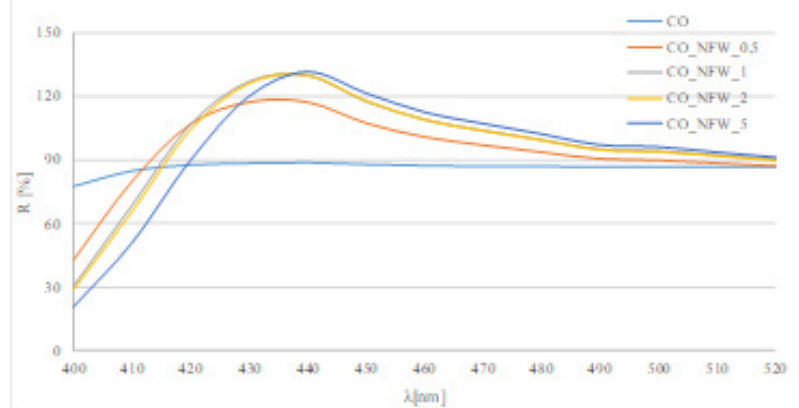

c)

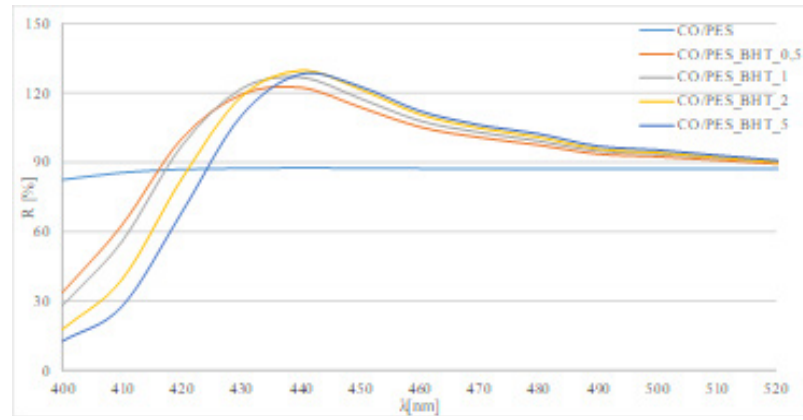

e)

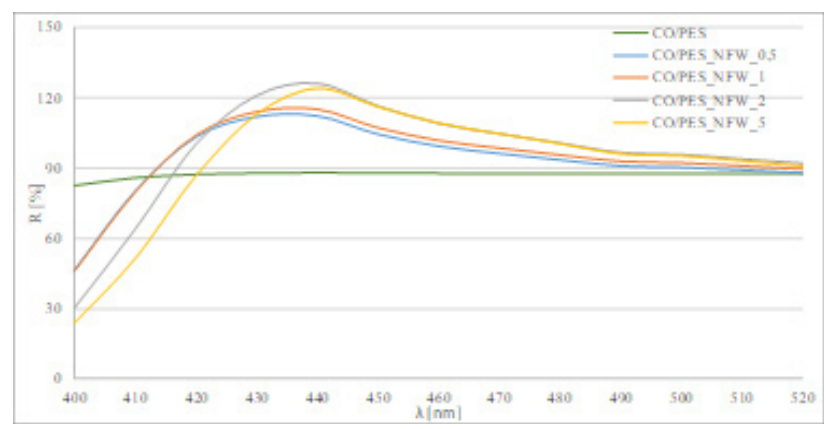

g)
The degree of whiteness according to $\mathrm{CIE}$, corresponding Tint Deviations (TD) and its coloristic meanings according to Griesser are collected in Tables 3 and 4 .

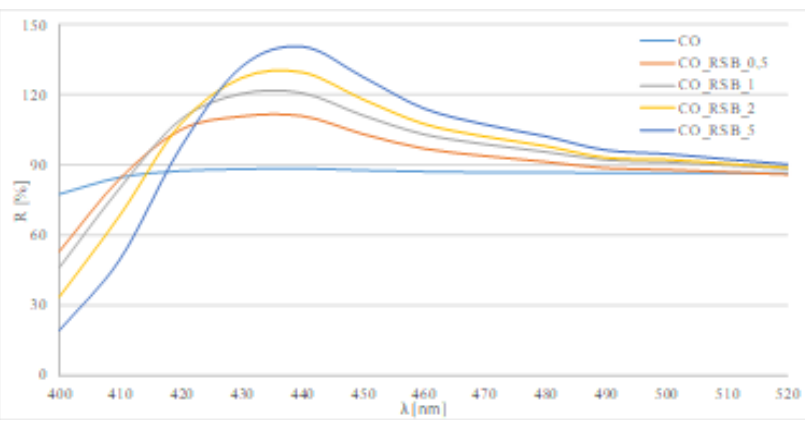

b)

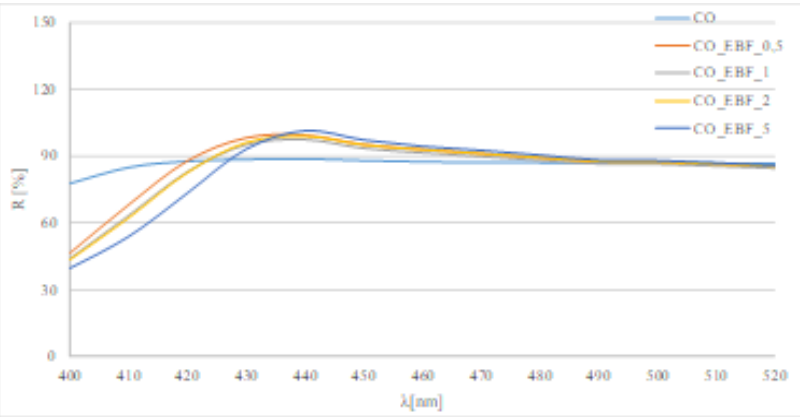

d)

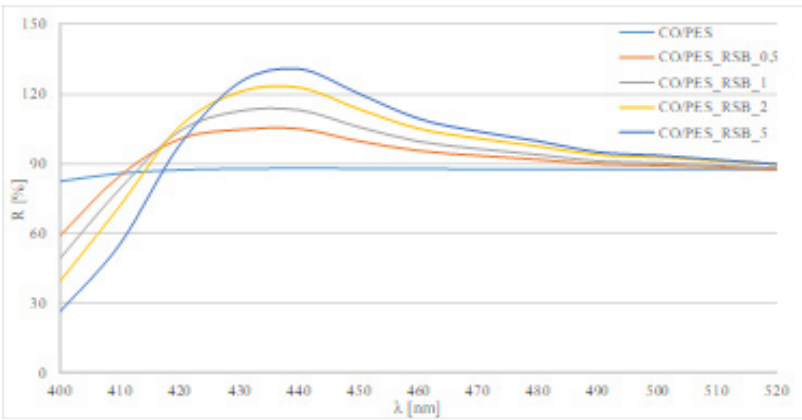

f)

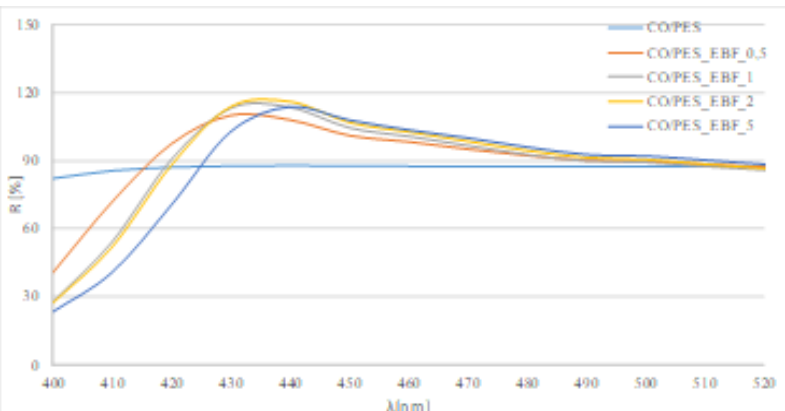

h)

Figure 1. Remission curves of $\mathrm{CO}$ and $\mathrm{CO} / \mathrm{PES}$ fabric before and after FWA treatment - a) $\mathrm{CO}$ BHT, b) CO_RSB, c) CO_NFW, d) CO_EBF, e) CO/PES_BHT, f) CO/PES_RSB, g) CO/PES_NFW, h) CO/PES_EBF 
Table 3. CIE whiteness $\left(\mathrm{W}_{\mathrm{CIE}}\right)$ of cotton fabrics after FWA treatment, maximum of remission $\left(R_{\max }\right)$ and wavelength $\left(\lambda_{\text {max }}\right)$, Tint Deviations (TD) and its coloristic meaning

\begin{tabular}{lccccc}
\hline Fabric & $\mathbf{W}_{\text {CIE }}$ & $\mathbf{R}_{\max }$ & $\begin{array}{c}\boldsymbol{\lambda}_{\max } \\
{[\mathbf{n m}]}\end{array}$ & TD & Coloristic meaning \\
\hline CO & 89.0 & 87.62 & 700 & & \\
CO_BHT_0.5 & 153.7 & 128.64 & 440 & $\mathrm{R} 1$ & Trace redder than the white scale \\
CO_BHT_1 & 157.6 & 133.37 & 440 & $\mathrm{R} 1$ & Trace redder than the white scale \\
CO_BHT_2 & 158.6 & 136.85 & 440 & & \\
CO_BHT_5 & 146.8 & 132.38 & 440 & $\mathrm{G} 2$ & Slightly greener than the white scale \\
CO_RSB_0.5 & 131.4 & 110.92 & 440 & $\mathrm{R} 2$ & Slightly redder than the white scale \\
CO_RSB_1 & 143.9 & 120.76 & 440 & $\mathrm{R} 2$ & Slightly redder than the white scale \\
CO_RSB_2 & 155.2 & 129.56 & 440 & $\mathrm{R} 2$ & Slightly redder than the white scale \\
CO_RSB_5 & 156.4 & 140.55 & 440 & $\mathrm{R} 1$ & Trace redder than the white scale \\
CO_NFW_0.5 & 140.1 & 117.43 & 430 & $\mathrm{R} 1$ & Trace redder than the white scale \\
CO_NFW_1 & 154.0 & 126.95 & 430 & $\mathrm{R} 1$ & Trace redder than the white scale \\
CO_NFW_2 & 154.2 & 130.10 & 440 & $\mathrm{R} 1$ & Trace redder than the white scale \\
CO_NFW_5 & 152.7 & 131.89 & 440 & $\mathrm{G} 1$ & Trace greener than the white scale \\
CO_EBF_0.5 & 110.1 & 99.63 & 440 & & \\
CO_EBF_1 & 105.1 & 97.33 & 440 & & \\
CO_EBF_2 & 106.7 & 98.86 & 440 & & \\
CO_EBF_5 & 106.9 & 101.51 & 440 & $\mathrm{G} 1$ & Trace greener than the white scale \\
\hline
\end{tabular}

Table 4. CIE whiteness $\left(\mathrm{W}_{\mathrm{CIE}}\right)$ of cotton/PES blended fabrics after FWA treatment, maximum of remission $\left(R_{\max }\right)$ and wavelength $\left(\lambda_{\max }\right)$, Tint Deviations (TD) and its coloristic meaning

\begin{tabular}{lccccc}
\hline Fabric & $\mathbf{W}_{\text {CIE }}$ & $\mathbf{R}_{\max }$ & $\begin{array}{c}\lambda_{\max } \\
\text { [nm] }\end{array}$ & TD & Coloristic meaning \\
\hline CO/PES & 88.0 & 87.63 & 700 & & \\
CO/PES_BHT_0.5 & 142.8 & 122.30 & 440 & & \\
CO/PES_BHT_1 & 144.1 & 127.07 & 440 & & \\
CO/PES_BHT_2 & 147.6 & 129.63 & 440 & & \\
CO/PES_BHT_5 & 141.9 & 128.32 & 440 & & \\
CO/PES_RSB_0.5 & 122.7 & 104.98 & 440 & $\mathrm{R} 1$ & Trace redder than the white scale \\
CO/PES_RSB_1 & 133.3 & 113.09 & 440 & $\mathrm{R} 1$ & Trace redder than the white scale \\
CO/PES_RSB_2 & 145.0 & 122.75 & 440 & $\mathrm{R} 1$ & Trace redder than the white scale \\
CO/PES_RSB_5 & 154.1 & 130.67 & 440 & & \\
CO/PES_NFW_0.5 & 136.2 & 112.42 & 440 & & \\
CO/PES_NFW-1 & 135.4 & 114.95 & 440 & & \\
CO/PES_NFW_2 & 145.9 & 126.41 & 440 & & \\
CO/PES_NFW_5 & 146.9 & 123.92 & 440 & $\mathrm{G} 1$ & Trace greener than the white scale \\
CO/PES_EBF_0.5 & 113.5 & 110.03 & 430 & $\mathrm{G} 1$ & Trace greener than the white scale \\
CO/PES_EBF_1 & 114.4 & 113.90 & 440 & $\mathrm{G} 1$ & Trace greener than the white scale \\
CO/PES_EBF_2 & 115.2 & 116.15 & 440 & $\mathrm{G} 1$ & Trace greener than the white scale \\
CO/PES_EBF_5 & 113.3 & 113.77 & 440 & $\mathrm{G} 2$ & Slightly greener than the white scale \\
\hline
\end{tabular}

From the results shown in Tables 3 and 4 it can be seen that untreated $\mathrm{CO}$ and CO/PES fabrics have remission at $700 \mathrm{~nm}$, and whiteness degree of 88 for $\mathrm{CO} /$ PES blend and 89 for cotton, with no appreciable deviation in tint from the white scale. In this paper, four FWAs of different constitutions and emission tones were used: Uvitex BHT, Uvitex RSB, Uvitex NFW and Uvitex EBF. By chemical composition stilbene derivatives are Uvitex BHT with high affinity for cotton (2 sulfonate groups) and Uvitex RSB with medium affinity (4 sulfonate groups). Uvitex NFW is a distyrylbiphenyl derivative, and Uvitex EBF benzoxazole derivative. Regardless of the chemical composition of FWA applied, treatment with the lowest concentration of FWA $0.5 \%$ owf leads to the significantly higher whiteness $\left(\mathrm{W}_{\mathrm{CIE}}>110\right)$ due to fluorescence emission at $430-440 \mathrm{~nm}$. The highest degree of whiteness is achieved with $2 \%$ of Uvitex BHT on cotton fabric (158.6).

From the results of spectral remission presented in Figure 2 and Tables 3 and 4 it can be seen that Uvitex NFW, EBF and BHT emit blue, whilst Uvitex RSB emits in red-purple part of spectrum. The highest whiteness and excellent brightness of both $\mathrm{CO}$ and CO/PES fabric for the blue ones was achieved when the concentration of $2 \%$ FWA was applied. However, for Uvitex BHT and
Uvitex NFW on the cotton fabric a concentration of $1 \%$ is sufficient to achieve excellent whiteness. On CO/PES blended fabric for Uvitex BHT, it is sufficient, whilst for Uvitex NFW, a higher concentration is needed. The reason for these results is the chemical composition of the fabric. Since the fabric is blended, only cotton adsorbs FWA, whilst polyester component does not. The opposite is true for Uvitex EBF, which is only adsorbed by polyester. Therefore, the degree of whiteness achieved with this FWA is lower than with other FWAs. It is also lower on cotton than on CO/PES blend. This can be explained by the fact that Uvitex EBF has no affinity for cotton fabric. For this reason, the use of Uvitex EBF is recommended for the treatment of polyester and its blends.

Spectral remission from fabrics treated with Uvitex RSB corresponds to a red-violet tone and shifts to blue at higher concentrations. Therefore, the highest applied concentration of $5 \%$ owf is considered the best. In bluetoned FWAs, Uvitex BHT and Uvitex NFW, concentration quenching of fluorescence is observed (decrease in whiteness and remission). Layering of FWA molecules at a high concentration prevents excitation of molecules in all layers and therefore there is no fluorescence that directly affects the reduction of whiteness. Additionally, 
FWA molecules at high concentrations build dimers that do not have the ability to fluoresce. This phenomenon is more enhanced for Uvitex BHT.

The UV protection of cotton and cotton/PES fabrics treated with FWA was determined according to AS/NZS 4399:2017. The influence of the FWAs concentration and constitution on UV protection was monitored through UV-A and UV-B transmission and the mean value of the UV protection factor (UPF). The results are collected in Tables 5 and 6.

The applied $\mathrm{CO}$ and CO/PES fabrics were woven in panama weave. These fabrics are soft to the touch, permeable to air or steam, which makes them suitable for comfortable summer clothes. From Table 5 it can be seen that even chemically bleached fabric $\mathrm{CO}$ has excellent UV protection (UPF=210). Due to the benzene rings in the polymer molecule, PES component in CO/PES blended fabric absorbs UV radiation leading to even higher excellent UV protection (UPF=804).

From the results shown in Tables 5 and 6 , it can be seen that the fluorescent whitening agent applied even at small concentration leads to a higher UPF for CO fabric, and to a maximum one for CO/PES blend (UPF=1000).

Table 5. Ultraviolet protection factor (UPF), UV-A and UV-B transmission, and UV protection rating according to AS/NZS 4399:2017 of cotton fabrics after FWA treatment with our different FWAs

\begin{tabular}{lcccccrr}
\hline \multicolumn{1}{c}{ Fabric } & UPF & $\tau$ UV-A & \multicolumn{2}{c}{$\begin{array}{c}\text { UVV-B } \\
\text { Stand. } \\
\text { dev. }\end{array}$} & $\begin{array}{c}\text { Stand. err. } \\
\text { UV } \\
\text { protection }\end{array}$ \\
\hline CO & 209.691 & 0.375 & 0.594 & 8.816 & 10.931 & $50+$ & Excellent \\
CO_BHT_0.5 & 1000.000 & 0.100 & 0.100 & 0 & 0 & $50+$ & Excellent \\
CO_BHT_1 & 1000.000 & 0.100 & 0.100 & 0 & 0 & $50+$ & Excellent \\
CO_BHT_2 & 1000.000 & 0.100 & 0.100 & 0 & 0 & $50+$ & Excellent \\
CO_BHT_5 & 1000.000 & 0.100 & 0.100 & 0 & 0 & $50+$ & Excellent \\
CO_RSB_0.5 & 765.406 & 0.115 & 0.111 & 55.063 & 68.278 & $50+$ & Excellent \\
CO_RSB_1 & 1000.000 & 0.100 & 0.100 & 0 & 0 & $50+$ & Excellent \\
CO_RSB_2 & 1000.000 & 0.100 & 0.100 & 0 & 0 & $50+$ & Excellent \\
CO_RSB_5 & 1000.000 & 0.100 & 0.100 & 0 & 0 & $50+$ & Excellent \\
CO_NFW_0.5 & 1000.000 & 0.100 & 0.100 & 0 & 0 & $50+$ & Excellent \\
CO_NFW_1 & 1000.000 & 0.100 & 0.100 & 0 & 0 & $50+$ & Excellent \\
CO_NFW_2 & 1000.000 & 0.100 & 0.100 & 0 & 0 & $50+$ & Excellent \\
CO_NFW_5 & 1000.000 & 0.100 & 0.100 & 0 & 0 & $50+$ & Excellent \\
CO_EBF_0.5 & 698.350 & 0.128 & 0.113 & 10.562 & 13.096 & $50+$ & Excellent \\
CO_EBF_1 & 905.645 & 0.105 & 0.104 & 18.488 & 22.925 & $50+$ & Excellent \\
CO_EBF_2 & 1000.000 & 0.100 & 0.100 & 0 & 0 & $50+$ & Excellent \\
CO_EBF_5 & 1000.000 & 0.100 & 0.100 & 0 & 0 & $50+$ & Excellent \\
\hline
\end{tabular}

Table 6. Ultraviolet protection factor (UPF), UV-A and UV-B transmission, and UV protection rating according to AS/NZS 4399:2017 of cotton fabrics after FWA treatment with our different FWAs

\begin{tabular}{lccccccr}
\hline \multicolumn{1}{c}{ Fabric } & UPF & $\tau$ UUv-A & \multicolumn{2}{c}{$\tau$ UV-B } & $\begin{array}{c}\text { Stand. } \\
\text { dev. }\end{array}$ & Stand. err. & $\begin{array}{c}\text { UV } \\
\text { protection }\end{array}$ \\
\hline CO/PES & 804.031 & 0.100 & 0.301 & 10.587 & 13.128 & $50+$ & Excellent \\
CO/PES_BHT_0.5 & 1000.000 & 0.100 & 0.100 & 0 & 0 & $50+$ & Excellent \\
CO/PES_BHT_1 & 1000.000 & 0.100 & 0.100 & 0 & 0 & $50+$ & Excellent \\
CO/PES_BHT_2 & 1000.000 & 0.100 & 0.100 & 0 & 0 & $50+$ & Excellent \\
CO/PES_BHT_5 & 1000.000 & 0.100 & 0.100 & 0 & 0 & $50+$ & Excellent \\
CO/PES_RSB_0.5 & 1000.000 & 0.100 & 0.100 & 0 & 0 & $50+$ & Excellent \\
CO/PES_RSB_1 & 1000.000 & 0.100 & 0.100 & 0 & 0 & $50+$ & Excellent \\
CO/PES_RSB_2 & 1000.000 & 0.100 & 0.100 & 0 & 0 & $50+$ & Excellent \\
CO/PES_RSB_5 & 1000.000 & 0.100 & 0.100 & 0 & 0 & $50+$ & Excellent \\
CO/PES_NFW_0.5 & 1000.000 & 0.100 & 0.100 & 0 & 0 & $50+$ & Excellent \\
CO/PES_NFW_1 & 1000.000 & 0.100 & 0.100 & 0 & 0 & $50+$ & Excellent \\
CO/PES_NFW_2 & 1000.000 & 0.100 & 0.100 & 0 & 0 & $50+$ & Excellent \\
CO/PES_NFW_5 & 1000.000 & 0.100 & 0.100 & 0 & 0 & $50+$ & Excellent \\
CO/PES_EBF_0.5 & 1000.000 & 0.100 & 0.100 & 0 & 0 & $50+$ & Excellent \\
CO/PES_EBF_1 & 1000.000 & 0.100 & 0.100 & 0 & 0 & $50+$ & Excellent \\
CO/PES_EBF_2 & 1000.000 & 0.100 & 0.100 & 0 & 0 & $50+$ & Excellent \\
CO/PES_EBF_5 & 1000.000 & 0.100 & 0.100 & 0 & 0 & $50+$ & Excellent \\
\hline
\end{tabular}

Since the phenomenon of fluorescence occurs in FWA molecules due to their electronically-excited state by UV-R energy, high whiteness of outstanding brightness is achieved by reemitting the energy at the blue region of the spectrum. Increment of FWA concentration leads to even higher UPF due to the absorption of UV-A radiation. For CO/PES blended fabrics, the maximum is reached at the lowest concentration, regardless of the chemical composition of the FVA. However, for cotton fabrics, it can be seen that Uvitex BHT and NFW, which gave the best whiteness at low concentration, gave maximum UV protection even at the lowest concentration. Uvitex RSB has UPF $=765$ at the lowest concentration, and maximum is achieved at higher concentration. As Uvitex EBF is for polyester, small difference in UPF can be observed. At concentrations 0.5 and $1 \%$ owf results of UPF are 698 and 905 respectively.

It should be noted that the fabrics with the highest intensity of fluorescence do not show the highest UPF values. UV protection increases with FWA concentration, 
regardless of quenching phenomenon.

Comparing the results on $\mathrm{CO}$ and CO/PES fabrics it can be seen that better results were achieved on cotton fabrics for Uvitex BHT and Uvitex NFW. The reason for this is their affinity for cellulose fibers. Uvitex RSB gave similar results on $\mathrm{CO}$ and CO/PES blended fabrics, whilst Uvitex EBF gave better results on the blend due to its affinity for polyester fibers, but significantly lower than the other three FWAs applied.

Comparing the results of UV protection on $\mathrm{CO}$ and CO/PES fabrics it can be seen that slightly better results were also achieved on blended fabrics. This is due to benzene rings in the polyester polymer molecule.

\section{Conclusions}

It can be concluded that it is essential to choose the right fluorescent whitening agents according to theirchemical constitution and concentration, depending on the composition of the fabric being treated. Otherwise, high whiteness results will not be achieved. Uvitex BHT, Uvitex RSB and Uvitex NFW provide high whiteness on both cotton and cotton/polyester blend fabrics. All three FWAs can be applied on a cotton fabric. However, for usage on a cotton/polyester blend Uvitex RSB gives the best results. All FWAs contribute to an increase in UV protection even at the lowest concentration. Regardless of quenching, the achieved UV protection at higher concentrations does not decrease.

According to the results obtained, the diamino stilbene disulphonic acid derivative (C.I. Fluorescent Brightener 113, Uvitex BHT) or a distyryl biphenyl derivative (C.I. Fluorescent Brightener 351, Uvitex NFW) at a concentration of $1 \%$ owf can be recommended for the use on cotton, whilst the stilbene disulphonic acid triazine derivative (Uvitex RSB) in concentration of $5 \%$ owf can be recommended for the use on cotton/polyester blended fabric.

\section{Acknowledgment}

This work has been supported in part by Croatian Science Foundation under the project UIP-2017-05-8780 HPROTEX.

This work is a result of Croatia-Serbia cooperation in science and technology 2019-2021 entitled "Bio-innovative polyesters".

\section{References}

[1] I. Soljačić, O optičkim bjelilima, Tekstil, 21(5) (1972) 377398.

[2] A. M. Grancarić, I. Soljačić, Einfluss der Konzentration optischer Aufheller auf Fluoreszenz und Weissgrad von Baumwollgeweben, Melliand Textilber, 62(11) (1981) 876882.

[3] A. M. Grancarić, A. Tarbuk, Quenching of Fluorescence in World of Whiteness in Book of Papers of 11th AIC 2009, The Colour Society of Australia, Sydney 2009, p. 395-401.
[4] T. Dekanić, T. Pušić, I. Soljačić, B. Vojnović, J. Volmajer Valh, The Influence of Iron Ions on Optical Brighteners and Their Application to Cotton Fabrics, Materials, 14(17) (2021) 4995, 14.

[5] T. Dekanić, A. Tarbuk, T. Pušić, A. M. Grancarić, I. Soljačić, Light Conversion for UV Protection by Textile Finishing and Care, Chapter 8 in Sunscreens: Properties, Role in Skin Cancer Prevention and Health Effects, Ed. S. H. Sharp, Nova Science Publishers, New York 2015, p. 143172.

[6] A. Tarbuk, A. M. Grancarić, M. Šitum, Skin cancer and UV Protection, AUTEX research journal, 16(1) (2016) 19-28.

[7] A. Riva, I. Algaba, R. Prieto, Optical Brightening Agents Based on Stilbene and Distyryl Biphenyl for the Improvement of Ultraviolet Protection of Cotton Fabrics, Tekstil 56(1) (2007) 1-6.

[8] A. M. Grancarić, A. Tarbuk, I. Dumitrescu, J. Bišćan, Influence of Fluorescent Whitening Agent on Ultraviolet Protection of Pretreated Cotton, AATCC Review, 6(4) (2006) 44-48.

[9] A. M. Grancarić, A. Tarbuk, L. Botteri, Light Conversion and Scattering in UV Protective Textiles, AUTEX Research Journal, 14(4) (2014) 247-258.

[10] I. Čorak, T. Dekanić, P. Kašaj, A. Tarbuk, The optimization of di(cyanstyryl) derivative application to polyester fabric and its blend, in Book of Proceedings 13th International Scientific Professional Symposium Textile Science \& Economy, Eds. S. Petrak, E. Zdraveva, B. Mijović, University of Zagreb Faculty of Textile Technology, Zagreb 2020, p. 45-50.

[11] A. Tarbuk, A. M. Grancarić, M. Šitum, Discrepancy of Whiteness and UV Protection in Wet State. Collegium antropologicum, 38(4) (2014) 1099-1105.

[12] A. Tarbuk, A. M. Grancarić, I. Jančijev, S. Sharma, Zaštita od ultraljubičastog zračenja površinski modificiranom poliesterskom tkaninom, Tekstil, 55(8) (2006) 383-394.

[13] Y. Zhou, P. Cox Crews, Effect of OBAs and repeated launderings on UVR transmission through fabrics, Textile Chemist and Colorist, 30(11) (1998) 19-24.

[14] T. Dekanić, I. Soljačić, T. Pušić, Impact of artificial light on optical and protective effects of cotton after washing with detergent containing fluorescent compounds, Tenside, surfactants, detergents, 51(5) (2014) 451-459.

[15] A. Tarbuk, A. M. Grancarić, M. Šitum, M. Martinis, UV Clothing and Skin Cancer, Collegium Antropologicum, 34(S2) (2010) 179-183.

[16] P. H. Gies, C. R. Roy, S. Toomey, A. Mclennan, Protection against solar ultraviolet radiation, Mutation Research 422 (1998) 15-22.

[17] D. Saravanan, UV protection textile materials, AUTEX Research Journal, 7 (2007) 53-62.

[18] G. Reinert, F. Fuso, R. Hilfiker, E. Schmidt, UV-protecting properties of textile fabrics and their improvement, Textile Chemist and Colorist, 29(12) (1997) 36-43.

[19] I. Algaba, A. Riva, P. C. Crews, Influence of Fiber Type and Fabric Porosity on the UPF of Summer Fabrics, AATCC Review, 4(2) (2004) 26-31.

[20] A. M. Grancarić, Ž. Penava, A. Tarbuk, UV Protection of Cotton - the Influence of Weaving Structure, Hemijska industrija, 59(9-10) (2005) 230-234.

[21] R. Griesser, Assessment of whiteness and tint of fluorescent substrates with good inter-instrument correlation, Color Res. Appl. 19(6) (1994) 446-460. 
Izvod

\section{UTICAJ HEMIJSKOG SASTAVA OPTIČKOG SREDSTVA ZA BELJENJE NA BELINU I UV ZAŠTITU PAMUKA I MEŠAVINE PAMUK/POLIESTAR}

Lea Botteri ${ }^{1}$, Tihana Dekanić ${ }^{1}$, Anita Tarbuk ${ }^{1}$, Dragan Đorđević ${ }^{2}$

${ }^{1}$ Sveučilište u Zagrebu Tekstilno-tehnološki fakultet, Zagreb, Hrvatska

2Univerzitet u Nišu, Tehnološki fakultet u Leskovcu, Leskovac, Srbija

Dobro je poznato da optimalna koncentracija fluorescentnog optičkog sredstva za beljenje (FWA) u kupatilu rezultira visokom belinom jednokomponentnog tekstila. Istovremeno, zahvaljujući fluorescenciji FWA, postiže se i veća UV zaštita. Međutim, za mešavine tekstila to nije tako lako postići. U zavisnosti od hemijskog sastava tekstila, moraju se primeniti različite FWA. Zato je u ovom radu istražen uticaj hemijskog sastava FWA na belinu i UV zaštitu pamuka i mešavine pamuk/poliestar. U tu svrhu, pamučna tkanina i tkanina iz mešavine pamuk/poliestar (50\%/50\%) obrađene su sa četiri različita optička sredstva za beljenje od Huntsmana, marke Uvitex®: BHT, RSB, NFW i EBF. Spektralna remisija pre i posle obrade sa FWA merena je na remisionom spektrofotometru Spectraflash SF 300, Datacolor. Stepen beline je izračunat prema ISO 105-J02:1997, odstupanja nijanse i njegova koloristička značenja određena su prema Griesseru. UV zaštita pamuka i pamuk/poliestar tkanina obrađenih sa FWA određena je prema AS/NZS 4399:2017 korišćenjem transmisionog spektrofotometra Cary 50/Solascreen, Varian. Prema postignutim rezultatima, derivat triazinske kiseline na osnovu stilben disulfonske kiseline (Uvitex® RSB) može se preporučiti za upotrebu na mešavini pamuk/poliestar.
(ORIGINALNI NAUČNI RAD)

UDK 677.21/.494.674:677.26

DOI 10.5937/savteh2102066B

Ključne reči: pamuk, mešavina pamuk/ poliestar, UV zaštita, FWA, stepen beline 